\title{
Current extraction techniques towards bioactive compounds from brewer's spent grain - A review
}

\author{
T. Bonifácio-Lopes ${ }^{\mathrm{a}, \mathrm{b}}\left(\mathbb{D}\right.$, José A. Teixeira ${ }^{\mathrm{a}}(\mathbb{D})$, and Manuela Pintado ${ }^{\mathrm{a}}$
}

${ }^{a} \mathrm{CBQF}$ - Centro de Biotecnologia e Química Fina - Laboratório Associado, Escola Superior de Biotecnologia, Universidade Católica Portuguesa, Porto, Portugal; ${ }^{\mathrm{b}} \mathrm{CEB}$ - Centre of Biological Engineering, University of Minho, Braga, Portugal

\begin{abstract}
Background: Brewer's spent grain is one of the most abundant by-products of the brewing industry and is rich in various bioactive compounds (phenolic acids, insoluble dietary fiber and proteins). While at the present brewer's spent grain is mainly used as animal feed its rich nutritional content makes it an interesting alternative for food applications. Scope and approach: As the range of applications of the bioactive compounds extracted from by-products has been growing in recent years, there is the need to obtain and characterize these bioactive compounds. Extraction methods (supercritical carbon dioxide, autohydrolysis, alkaline hydrolysis, solvent extraction, ultrasound assisted extraction, dilute acid hydrolysis, enzymatic hydrolysis, microwave assisted extraction) have been developed and are always being subjected to new approaches to allow better extraction yields of the bioactive compounds. Key findings and conclusions: This review aims to provide a better understanding of the current advantages and limitations of brewer's spent grain extraction processes and to provide a background of brewer's spent grain composition and applications.
\end{abstract}

\section{HIGHLIGHTS}

- The re-use of agro-industrial by-products can origin new added-value products

- BSG is an agro-industrial by-product and is a source of various bioactive compounds

- Extraction methods have been applied to extract these compounds from BSG

- It is needed to find new techniques and new possible applications to the BSG

\section{KEYWORDS}

Bioactive compounds: brewer's spent grain; chemical composition; extraction techniques

\section{Introduction}

One of the food waste objectives to reach Sustainable Development Goal (SDG) is to halve food waste by 2030 assuming that today around 100 million tons of food are wasted every year in the European Union (EU). The action plan to reduce food waste envisioned by the EU action plan for the circular economy, which is a strategic and operational approach based on the reduction, reuse, recovery and recycling of materials and energy, enhancing the value and consequently the useful life of products, materials and resources in the economy. The re-use of agro-industrial byproducts can give origin to new added-value products with functional compounds and the addition of functional compounds will benefit the industry and the consumers; the industry from an economic point of view and the consumers through the use of high valuable bioactive compounds that besides the health benefits may also replace positively the synthetic additives (Fărcaş et al. 2015; Spinelli et al. 2016).

Beer is one of the most commonly consumed beverages in the world and global beer production was of 190.90 million kiloliters in 2017 being China the largest beer producing country (38.79 million kiloliters) followed by the United States of America (21.78 million kiloliters) and Brazil (14.00 million kiloliters) (Kirin Holdings 2018). Brewer's spent grain (BSG) is one of the most abundant by-product of the brewing industry. Currently, one of the most common use of BSG is animal feed but has certain characteristics (both nutritional and functional) that makes of BSG a good added-value by-product.

BSG is a source of bioactive compounds such as phenolic acids, insoluble dietary fiber or proteins, compounds with a particular interest for the industry and the elaboration of added-value products (Lynch, Steffen, and Arendt 2016; McCarthy et al. 2012; Mussatto, Dragone, and Roberto 2006; Mussatto 2014; Steiner, Procopio, and Becker 2015; Vieira et al. 2014). Spent grains are the solid residue separated from the beer wort by filtration after the mashing phase of the brewing process and are obtained from barley and constitute the insoluble fraction of the wort (del Río, Prinsen, and Gutiérrez 2013; Pires et al. 2012; Vieira et al. 2014). Therefore, the purpose of the present review is to provide a comprehensive and critical analysis of the techniques currently used to attain bioactive compounds from BSG as well 
Table 1. BSG composition.

\begin{tabular}{|c|c|}
\hline $\begin{array}{l}\text { Major components } \\
\text { Cellulose (qlucan) }\end{array}$ & $\begin{array}{l}\mathbf{g ~ k g}^{-1} \text { dry weight basis } \\
-330\end{array}$ \\
\hline $\begin{array}{l}\text { Cellulose (glucan) } \\
\text { Hemicellulose }\end{array}$ & $\begin{array}{l}3-330 \\
192-419\end{array}$ \\
\hline Xylan & $136-206$ \\
\hline Arabinan & $56-419$ \\
\hline Starch & $10-120$ \\
\hline Lignin & $115-278$ \\
\hline Lipids & $30-106$ \\
\hline Acetyl groups & $11-14$ \\
\hline Proteins & $142-310$ \\
\hline Ashes & $11-46$ \\
\hline Extractives & $58-107$ \\
\hline Phenolics & $7-20$ \\
\hline Minerals & $\mathrm{mg} \mathrm{kg}^{-1}$ dry weight basi \\
\hline Silicon & $1400-10,740$ \\
\hline Phosphorus & $4600-6000$ \\
\hline Calcium & $2200-3515$ \\
\hline Magnesium & $1900-2400$ \\
\hline Sulfur & $1980-2900$ \\
\hline Potassium & $258.1-700$ \\
\hline Sodium & $100-309.3$ \\
\hline Iron & $100-193.4$ \\
\hline Zinc & $82.1-178$ \\
\hline Aluminium & $36-81.2$ \\
\hline Manganese & $40.9-51.4$ \\
\hline Cobalt & 17.8 \\
\hline Copper & $11.4-18$ \\
\hline Strontium & $10.4-12.7$ \\
\hline lodine & 11 \\
\hline Barium & $8.6-13.6$ \\
\hline Chromium & $<0.5-5.9$ \\
\hline Molybdenum & 1.4 \\
\hline Boron & 3.2 \\
\hline Amino acids & $\%$ of total protein \\
\hline \multicolumn{2}{|l|}{ Non-essential } \\
\hline Histidine & 26.27 \\
\hline Glutamic acid & 16.59 \\
\hline Aspartic acid & 4.81 \\
\hline Valine & 4.61 \\
\hline Arginine & 4.51 \\
\hline Alanine & 4.12 \\
\hline Serine & 3.77 \\
\hline Tyrosine & 2.57 \\
\hline Glycine & 1.74 \\
\hline Asparagine & 1.47 \\
\hline Glutamine & 0.07 \\
\hline \multicolumn{2}{|l|}{ Essential } \\
\hline Lysine & 14.31 \\
\hline Leucine & 6.12 \\
\hline Phenylalanine & 4.64 \\
\hline Isoleucine & 3.31 \\
\hline Threonine & 0,71 \\
\hline Tryptophan & 0.14 \\
\hline
\end{tabular}

Adapted from Mussatto (2014) and Lynch, Steffen, and Arendt (2016).

as exploit its potentialities as source of addedvalue compounds.

\section{BSG composition}

BSG is composed of husk, pericarp and endosperm of barley grain (Lynch, Steffen, and Arendt 2016). BSG chemical composition may vary according to the barley variety, the harvest time, the conditions of malting and mashing, and the type of other constituents added during the brewing process. However, BSG, is normally chemically composed by: $24 \%$ non-cellulosic polysaccharides (namely arabinoxylans - AX), (1-3, 1-4)- $\beta$-D-glucan), 20\% lignin, 20\% cellulose (glucose), $21 \%$ protein, $10 \%$ lipids and $5 \%$ of ash. Hemicellulose (xylose and arabinose) and small amounts of starch can also be present (Mussatto, Dragone, and Roberto 2006). A detailed description of BSG composition is presented in Table 1.

The BSG also contain high content of diverse minerals (calcium, cobalt, copper, iron, magnesium, manganese, phosphorus, potassium, selenium, sodium and sulfur), vitamins (biotin, choline, folic acid, niacin, pantothenic acid, riboflavin, thiamin and pyridoxine) and free essential amino acids (leucine, valine, threonine, and lysine) and non-essential amino acids (alanine, serine, glycine, glutamic acid, aspartic acid, tyrosine, proline, arginine) that confer it relevant nutritional value. In addition to these components, BSG contain phenolic compounds, being the most important class the hydroxycinnamic acids (ferulic and p-coumaric acids derivates being the main ones). Ferulic and p-coumaric acids have demonstrated antioxidant, antiallergenic, anti-inflammatory and antimicrobial (mainly ferulic acid) properties and the extracts with these phenolic compounds may represent a new source of functional ingredients to be applied in the food development. European Food Safety Authority (EFSA), has recently accepted AX (from wheat endosperm) and (1-3,1-4)- $\beta$-glucan (from oatmeal, oat bran, barley, barley bran, or mixtures of these sources) as health beneficial bioactive compounds (Comissão Europeia 2012).

\section{BSG applications}

Nowadays, BSG is mainly used in animal nutrition. The main market is dairy cattle feed but as BSG provides, among other nutrients, protein and fiber, it is starting to be used to feed other animals as pigs, fish and poultry. As it is a bioactive compound and a low-cost product can also be used in human nutrition. Some products were already developed with BSG incorporated, like flours and bakery products. By ingesting BSG the human health can benefit as BSG is proved to increase fecal weight, accelerate transit time, reduce plasma cholesterol and fat excretion and decrease gallstones incidence (Mussatto 2014). Brewer's spent grain has interest as a source of energy and charcoal production. Thermochemical conversion such as combustion and pyrolysis are some of the alternative uses to BSG. By using BSG in combustion process the resultant energy can be used to help to suppress the energetic demand of the breweries. Nonetheless, the combustion of BSG will develop the emission of toxic gases and particles that contain sulfur dioxide and nitrogen. Pyrolysis of BSG results in the formation of char, bio-oil and permanent gases, being bio-oil the most abundant fraction and contains a complex mixture of hydrocarbons (Mussatto 2014). Gonçalves et al. (2017) studied the conversion of BSG to bio-oil and activated carbon, producing yields of $19 \%, 56 \%$ and $25 \%$ of charcoal, liquid (two phases - aqueous and organic (bio-oil)) and gases, respectively. Due to its high content of hemicellulose and cellulose, BSG can also be an interesting source of ethanol production (with a $86.3 \%$ conversion efficiency using dilute acid hydrolysis) (Mussatto 2014). Because of its lower content in ash and high amount of fibrous materials, BSG, can be used in charcoal brick production. Dried BSG is pressed and carbonized in low-oxygen atmosphere and the resultant bricks 


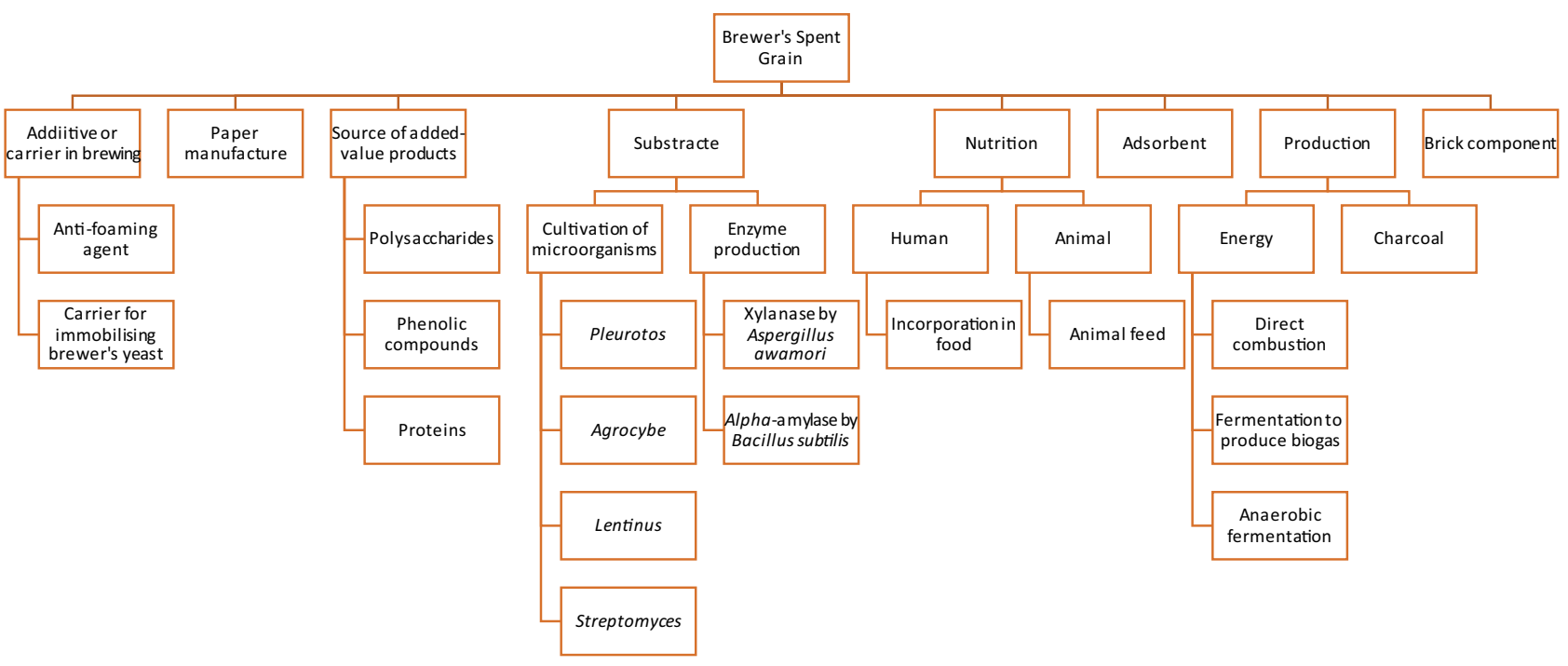

Figure 1. Summary of BSG applications.

have high calorific value and the burning properties are low due to the higher temperature ignition and longer burning period. The lower content in ash and high amount of fibrous materials also make BSG useful in paper manufacture (it can be used, for instance, to prepare paper towels, business cards and coasters) (Mussatto 2014). The low cost and easily availability of BSG make it interesting as an adsorbent as it removes either organic compounds from waste gases or dyes from wastewater. BSG without any treatment is capable of adsorb a common dye used in the paper and textile industries present in effluents. Activated carbons with similar and better adsorption capacity than others can also be produced by lignin present in BSG (Mussatto 2014; Silva et al. 2004). Mussatto et al. (2010) used ligin from BSG to prepare activated carbon, using phosphoric acid as an impregnating agent, by chemical activation. the best result was the one using $3 \mathrm{~g}$ of phosphoric acid/g of lignin at $600^{\circ} \mathrm{C}$. Due to being rich in polysaccharides and in associated proteins and minerals, BSG has several applications in the biotechnological processes as: substrate for cultivation of microorganisms and enzyme production; carrier for cell immobilization; additive or carrier in brewing and source of value-added products (Mussatto, Dragone, and Roberto 2006; Mussatto 2014) (Figure 1).

\section{BSG in foods and health}

Several compounds found in BSG can be isolated and applied in food to develop new functional foods, and the protein content in BSG might be exploited for human nutrition. McCarthy et al. (2013a), described the ability of BSG protein isolates to decrease, with great significance, proinflammatory cytokine IFN- $\gamma$ production, making these isolates useful in the treatment of inflammatory diseases (Coelho et al. 2014; McCarthy et al. 2013a, 2013b, Meneses et al. 2013; Mussatto and Roberto 2006; Mussatto, Dragone, and Roberto 2006; Steiner, Procopio, and Becker 2015). Human body produces free radicals as a by-product of metabolic processes and the defense system (various enzymes such as catalase, superoxide dismutase and glutathione peroxidase take part in this system), will, normally, detoxify the free radicals produced. There are some dietary antioxidants (vitamins $\mathrm{C}, \mathrm{E}$ and $\mathrm{A}$ ) that are able to detoxify the free radicals, yet, sometimes, there is an over-production of the free radical - oxidative stress. This oxidative stress leads to oxidative damage in cellular components and biomolecules and may result in diseases. Plants and cereals are rich in phenolic compounds and are being used as natural sources of antioxidants and can be useful in detoxifying the free radicals and, thus, reduce the oxidative stress. Plant and cereals antioxidants can be also used in foods to retard the oxidative deterioration of lipids (Gangopadhyay et al. 2016; Muniandy, Shori, and Baba 2015).

Brewer's spent grain are also rich in prebiotics and according to Gibson et al. (2017) prebiotics are "a substrate that is selectively utilized by host microorganisms conferring a health benefit". Fructooligosaccharides (FOS), galactooligosaccharides (GalOS), inulin and lactulose are known prebiotics. Additionally, $\beta$-glucan reportedly has prebiotic potential by stimulating the growth of lactobacilli and bifidobacterium in the gastrointestinal tract (Caleffi et al. 2015; Gómez et al. 2015; Mitsou et al. 2010; Wang et al. 2015). (1-3,1-4)- $\beta$-Dglucan and AX, are also present in BSG and have health claims associated (the intake of at least $3 \mathrm{~g}$ of barley (1-3,1$4)-\beta$-D-glucan is needed to lower/reduce blood cholesterol). Barley $\beta$-glucans were able to reduce/lower blood cholesterol. Arabinoxylans contribute to the reduction of the glucose rise after a meal (a consumption of $8 \mathrm{~g}$ of AX-rich fiber (from the wheat endosperm) per $100 \mathrm{~g}$ of available carbohydrates is needed) (Steiner, Procopio, and Becker 2015).

Arabinoxylans and arabinoxylooligosacharides (AXOS) are considered to be good potential prebiotics because they are nondigestible oligosaccharides by gastric or pancreatic enzymes, promote the good environment of the gastrointestinal tract and some groups of beneficial gut microflora are able to use them, conferring benefits to the health of the host. Arabinoxylooligosacharides are more resistant to heat and acidic $\mathrm{pH}$ when compared to $\mathrm{AX}$ and FOS due to their 
Table 2. Summary of different phenolic compounds extraction methodologies and possible applications of BSG.

\begin{tabular}{|c|c|c|c|c|}
\hline Extraction method & Extraction conditions & Target compounds & Foreseen applications & Reference \\
\hline $\begin{array}{l}\text { Supercritical carbon } \\
\text { dioxide extraction }\end{array}$ & $\begin{array}{l}\text { Pressure: } 15-35 \mathrm{MPa} \text {; } \\
\text { temperature: } 40-60{ }^{\circ} \mathrm{C} \text {; } \\
\mathrm{CO}_{2}+\text { ethanol: } 0-60 \% \mathrm{v} / \mathrm{v} \text {. } \\
\text { Best conditions: } 240 \mathrm{~min} \text {. } \\
\text { temperature of } 40{ }^{\circ} \mathrm{C} \text {, } \\
\text { pressure of } 35 \mathrm{MPa} \text { and } \\
\mathrm{CO}_{2}+60 \% \text { ethanol }(\mathrm{v} / \mathrm{v}) \text {. } \\
\text { Phenolic: }(0.35 \pm 0.01 \mathrm{mg} / \mathrm{g} \\
\text { BSG); flavonoid: } \\
\text { (0.22 } 0.01 \mathrm{mg} / \mathrm{g} \mathrm{BSG}) ; \\
\text { antioxidant } \\
\text { properties:(2.09 } \pm 0.04 \% / \\
\text { g BSG) }\end{array}$ & Phenolic compounds & $\begin{array}{l}\text { Potential re-use of this } \\
\text { brewery by-product and } \\
\text { the possibility to achieve a } \\
\text { promising system for a } \\
\text { large-scale extraction }\end{array}$ & Spinelli et al. (2016) \\
\hline Autohydrolysis & $\begin{array}{l}\text { Solid/liquid ratios: } 1 / 10 \text { and } \\
1 / 30 \mathrm{~g} \mathrm{BSG} / \mathrm{ml} \text { water; } \\
\text { temperature: } 121{ }^{\circ} \mathrm{C} \text {; time: } \\
10 \text { or } 90 \text { min. Hydrolysate } \\
\text { with the most pleasant } \\
\text { aroma was obtained with } \\
1 \mathrm{~g} \mathrm{BSG} / 10 \mathrm{ml} \text { water }\end{array}$ & Phenolic compounds & $\begin{array}{l}\text { The compounds extracted can } \\
\text { be reused in the } \\
\text { production of food } \\
\text { or beverages. }\end{array}$ & Meneses et al. 2011 \\
\hline Alkaline hydrolysis & $\begin{array}{l}\mathrm{NaOH} 1.0 ; 1.5 \text { and } 2.0 \% \mathrm{w} / \mathrm{v} \text {; } \\
\text { temperature: } 80,100 \text { and } \\
120^{\circ} \mathrm{C} \text {; reaction times: } 30 \text {, } \\
60 \text { and } 90 \text { min. Best } \\
\text { hydrolysis conditions: } 2 \% \\
\mathrm{NaOH}, 120^{\circ} \mathrm{C} \text { and } 90 \mathrm{~min} \\
\text { obtaining } 145.3 \mathrm{mg} / \mathrm{l} \\
\text { ferulic acid and } 138.8 \mathrm{mg} / \mathrm{l} \\
\text { p-coumaric. }\end{array}$ & Ferulic and p-coumaric acids. & $\begin{array}{l}\text { Re-use of BSG in the food, } \\
\text { cosmetic and/or } \\
\text { pharmaceutical fields. } \\
\text { Further assessments of the } \\
\text { acceptability and safety of } \\
\text { the phenolic acids } \\
\text { extracted from BSG } \\
\text { are necessary. }\end{array}$ & $\begin{array}{l}\text { Mussatto, Dragone, and } \\
\text { Roberto } 2007\end{array}$ \\
\hline Solvent extraction & $\begin{array}{l}\text { Water; } 100 \%, 80 \%, 60 \%, 40 \% \\
\text { and } 20 \% \text { of methanol, } \\
\text { ethanol and acetone } \\
\text { mixtures with water, } 100 \% \\
\text { of ethyl acetate and } \\
\text { hexane. Most content of } \\
\text { total phenols and } \\
\text { antioxidant potential: } \\
\text { acetone:water } 60 \% \text {. }\end{array}$ & Phenolic compounds & $\begin{array}{l}\text { Applications in the food, } \\
\text { cosmetic and } \\
\text { pharmaceutical industries, } \\
\text { since antioxidant phenolic } \\
\text { compounds could be used } \\
\text { as a natural and } \\
\text { inexpensive alternative to } \\
\text { synthetic antioxidants. }\end{array}$ & Meneses et al. 2013 \\
\hline
\end{tabular}

longer chain and the linkages between their constituents which makes of them interesting food ingredients (Courtin et al. 2009). Because BSG contains polymeric/oligomeric material composed of xylose BSG could also be used as a source of AXOS. For instance, some studies state that feruloylated AXOS have good antioxidant and radical scavengers properties (Aguedo et al. 2015; Coelho et al. 2014; Gómez et al. 2015; Reis et al. 2015). McCarthy et al. (2012) explored the antioxidant activity of phenolic extracts of BSG. The phenolic extracts showed to protect against oxidative DNA damage and against genotoxic effects of hydrogen peroxide and 3-morpholinosydnonimine hydrochloride (SIN-1).

\section{Extraction of added-value compounds}

Various types of extraction methods can be used to extract certain compounds from BSG like phenolic compounds, $\beta$-glucans or dietary fiber. The cost, time and availability of the process are variables that influence the choice of the most appropriate method. The extracts obtained can expand BSG applications, providing other uses than animal feed.

\section{Pretreatment advantages}

To break down the structure of the material in study it is usual to do a pretreatment stage such as acid hydrolysis, autohydrolysis, dilute acid, alkaline hydrolysis and others. The pretreatment improves the extraction efficacy allowing for an improvement of the extraction yields both in modern high-tech extraction approaches and in classic, less expensive, methodologies. Moreover, phenolic compounds are contained within the cell vacuole and are easily extracted if the solvent access to these structures is facilitated (Silva et al. 2017). Pretreatment methods like autohydrolysis, dilute acid, alkaline or enzymatic hydrolysis and others can be used to help extract phenolic and carbohydrates compounds. Selection of pretreatment method to use will depend on what type of compound that is wanted to extract. The pretreatment helps to preserve the pentose fractions, limit the formation of degradation compounds that will prevent the development of fermentative microorganisms and minimize the energy and costs (del Campo et al. 2006).

Autohydrolysis is a pretreatment used in the extraction of hemicelluloses. In this type of method, no chemicals are used which makes of it an interesting alternative as it is ecofriendly. Autohydrolysis has been used to remove hemicelluloses and too high temperatures decrease the amount of hemicelluloses recovered (Li et al. 2017).

Dilute acid pretreatment helps to deconstruct the cell wall of plants. Despite the fact that is low cost, it can lead to the production of acetic and formic acid and other inhibitors of enzymatic saccharification and fermentation 
microorganisms such as 5-hydroxymethylfurfural. Inorganic acids such as sulfuric, hydrochloric, nitric and phosphoric can be used, being the sulfuric acid the one used the most because it is the one with highest hemicellulose degradation efficiency. Dilute acid pretreatment is used in the production of bioethanol from agricultural waste (Mikulski and Kłosowski 2018; Rajan and Carrier 2014).

Just as autohydrolysis and dilute acid, alkaline acid pretreatment is environmentally friendly and low cost. The resulted biomass of alkaline pretreatment is enriched in cellulose. Alkaline pretreatment is normally applied to lignocellulosic materials, improving the biodegradability of the raw material by removing the lignin and increasing the porosity (Mancini et al. 2018; Shahabazuddin et al. 2018)

Enzymatic pretreatment is also a low-cost method as it does not require an expensive equipment, however the high cost of enzymes it is still a challenge when this method is used to the production of biogas at an industrial scale. This pretreatment can also be used to disrupt cell walls using low energy. This method uses oxidative and hydrolytic enzymes and most of these enzymes are not inhibited by the final products (Hosseini Koupaie et al. 2018; Zhang et al. 2018).

\section{Extraction of phenolic compounds}

As referenced above, some studies showed that BSG contains phenolic compounds such as ferulic and p-coumaric acids (Steiner, Procopio, and Becker 2015). In general, to extract bioactive compounds from BSG some extraction techniques have been used, namely solid-liquid extraction, microwave-assisted extraction, hydrothermal treatment and enzymatic and alkaline reactions (Table 2) (Steiner, Procopio, and Becker 2015).

To extract the phenolic compounds with antioxidant properties solid-to-liquid extraction can be used. Still, it is necessary to take in consideration the extraction solvent as this is an important factor when recovering these compounds (Meneses et al. 2013). To extract phenolic compounds as ferulic or p-coumaric acid, different methods have been investigated, namely alkaline hydrolysis with $\mathrm{NaOH}$, enzymatic extraction by adding esterease from Aspergillus niger or xylanase from Trichoderma viride (Bartolomé, Faulds, and Williamson 1997; Mussatto, Dragone, and Roberto 2007).

\section{Supercritical carbon dioxide}

In the extraction of phenolic compounds, supercritical fluid extraction can be a possible alternative. As this is a high cost process, it is mainly used as a technique to obtain high valuable substances and is fast, selective and there's no residual solvents. Carbon dioxide can be used as a solvent in supercritical fluid extraction. It has good solvation power when it is in the supercritical state and also it has gas-like and liquid-like qualities in this state. Carbon dioxide is cheap and is generally recognized as safe by the Food and Drug Administration (FDA) and EFSA. On the other hand, carbon dioxide has disadvantages being the main one its lower polarity. This problem can be solved with the use of co-solvents. However, the co-solvents might affect the efficiency of the extraction of antioxidants. One of the most used co-solvents in this kind of extraction is ethanol. The phenolic compounds extracted from this method can give to BSG a re-use (Junior, Leite, and Dragano 2014; Spinelli et al. 2016).

Spinelli et al. (2016) used supercritical carbon dioxide extraction to extract bioactive compounds from BSG using ethanol as a co-solvent. In this study, the conditions utilized to extract bioactive compounds from BSG were: pressure (15-35 MPa), temperature $\left(40-60^{\circ} \mathrm{C}\right)$ and $\mathrm{CO}_{2}+$ ethanol (0-60\% ethanol concentration $\mathrm{v} / \mathrm{v})$. The best conditions to extract antioxidant compounds were $240 \mathrm{~min}$., a temperature of $40{ }^{\circ} \mathrm{C}$, pressure of $35 \mathrm{MPa}$ and $\mathrm{CO}_{2}+60 \%$ ethanol (v/v), achieving a high phenolic $(0.35 \pm 0.01 \mathrm{mg} / \mathrm{g}$ BSG) and flavonoid $(0.22 \pm 0.01 \mathrm{mg} / \mathrm{g}$ BSG) content and good antioxidant properties $(2.09 \pm 0.04 \% / \mathrm{g} B S G)$.

\section{Autohydrolysis}

Autohydrolysis, also called hydrothermal treatment, is a technique that does not use chemical agents thus being a better option in comparison with the techniques that use chemical agents. This process uses liquid water under high temperature and pressure. In order to obtain the target compounds, the best reaction conditions need to be studied as these conditions are going to influence the products obtained by autohydrolysis (oligosaccharides, monosaccharides, sugar degradation products and acetic acid). Autohydrolysis is more environmentally friendly, not requiring chemical catalysts. The compounds extracted could be used in other industries such as food industries (Carvalheiro et al. 2005; Meneses et al. 2011; Ruiz et al. 2013).

Meneses et al. (2011) carried out BSG autohydrolysis (under different conditions) in order to extract aroma compounds. The autohydrolysis reactions were carried out in an autoclave under different solid/liquid ratios $(1 / 10$ and $1 / 30 \mathrm{~g}$ $\mathrm{BSG} / \mathrm{ml}$ water) at $121{ }^{\circ} \mathrm{C}$, during 10 or $90 \mathrm{~min}$. A group of untrained panelists attributed a value for the intensity of aroma perceived in each sample and additionally they also selected the sample considered having the most pleasant aroma. In this study aroma compounds were extracted and the condition to extract the most pleasant aroma was $1 \mathrm{~g}$ BSG/10 ml water with either 10 or $90 \mathrm{~min}$ of extraction.

\section{Alkaline hydrolysis}

Alkaline reagents disrupt the cell wall dissolving lignin and hemicelluloses. By removing lignin, the enzymatic hydrolysis yields improve (higher access of cellulolytic enzymes to cellulose) and lowers the probability of nonproductive enzyme binding to lignin. When using alkaline hydrolysis notbonded ferulic acid and p-coumaric acid can be released (Mussatto, Dragone, and Roberto 2007; Wilkinson, Smart, and Cook 2014; Xiao, Sun, and Sun 2001).

Mussatto, Dragone, and Roberto (2007) studied the extraction of ferulic and p-coumaric acids using alkaline 
hydrolysis. Different concentrations of $\mathrm{NaOH}(1,0 ; 1,5$ and $2,0 \% \mathrm{w} / \mathrm{v})$, different temperatures $\left(80,100\right.$ and $\left.120^{\circ} \mathrm{C}\right)$ and different reaction times $(30,60$ and $90 \mathrm{~min}$.) were used. It was concluded that the hydrolysis conditions that extracted more quantity of the compounds were $2 \% \mathrm{NaOH}$ concentration, $120^{\circ} \mathrm{C}$ and $90 \mathrm{~min}$, being obtained $145.3 \mathrm{mg} / \mathrm{l}$ ferulic acid and $138.8 \mathrm{mg} / \mathrm{l} \mathrm{p}$-coumaric acid. The obtained products can be used in food, cosmetic and pharmaceutical fields.

\section{Solvent extraction}

When using solvents to recover antioxidants, solid-to-liquid extraction is one of the most common methods used. The solvent, the temperature used, and the time of the extraction will influence the extraction efficiency.

Meneses et al. (2013) studied the extraction of phenolic compounds from BSG with different solvents (methanol, ethanol, acetone, hexane, ethyl acetate, water and mixtures of methanol, ethanol or acetone with water). The antioxidant potential and contents of phenols, flavonoids, reducing sugars and proteins in the extracts was also determined. Aqueous solutions - 100\%, 80\%, 60\%, 40\% and $20 \%$ - of methanol, ethanol and acetone were evaluated as well as pure ethyl acetate and hexane. All the extracts showed antioxidant activity but the one that had the highest content of total phenols and antioxidant potential was the one obtained with the aqueous solution of $60 \%$. The extract obtained using the solvent extraction method can be applied in food, pharmaceutical and cosmetic industries as it is an inexpensive alternative to synthetic antioxidants.

\section{Extraction of carbohydrates}

Various types of carbohydrates, like $\beta$-glucan, oligosaccharides or dietetic fiber can be found in BSG (Table 3).

In the process of extraction of AX, the BSG is pretreated with a solution of ethanol following two water extractions and pronase treatment. Arabinoxylans can be also extracted without the pretreatment using alkaline reagents. The AX can be recovered by the addition of ethanol and it is also possible to recover proteins by precipitation (Vieira et al. 2014).

Mild hydrothermal treatment of BSG might selectively release and degrade xylans (main component of hemicelluloses). This hydrothermal treatment of BSG may result in xylans and many differently substituted xylooligosaccharides. This treatment yields chains of (1-4)- $\beta$-xylan (single and double branched) with arabinose and xylooligosaccharides branched with arabinose. The reaction conditions of the treatment will influence the molecular weight and the amount of oligosaccharides released (Carvalheiro et al. 2004; Kabel, Schols, and Voragen 2002; Steiner, Procopio, and Becker 2015).

Using an alkali extraction method, AX will also be obtained (treatment with $\mathrm{Na}_{2} \mathrm{CO}_{3}$ and $\mathrm{KOH}$ ). The extracts obtained using an alkali method have an aggregation of feruloylated AX that is heterogeneous and has an extensive molecular weight (from 2,000,000 to 2,000 Da). Microwaveassisted extraction can be used to fractionate more the AX recovered from BSG. Microwave-assisted extraction has advantages in comparison to the conventional methods as the solvent mixture is heated rapidly (it takes only between 15 to $30 \mathrm{~min}$ ) and it uses small volumes of solvent (Steiner, Procopio, and Becker 2015).

In addition to the above-mentioned methods, there are also methods to extract (1-3,1-4)- $\beta$-glucan from BSG. The removal of (1-3,1-4)- $\beta$-glucan can be made with microwaveassisted extraction. There is a pretreatment of the BSG at mild temperature, removing the starch that it is mixed with (1-3,1-4)- $\beta$-glucan. Then, temperatures of $140^{\circ} \mathrm{C}$ are used to extract $\beta$-linked glucans without affecting the structure of the AX. Methods such as alkaline, solvent and enzymatic extraction have been used to extract (1-3,1-4)- $\beta$-glucan from barley and may be also used in the extraction of (1-3,1-4)$\beta$-glucan from BSG (Coelho et al. 2014; Steiner, Procopio, and Becker 2015).

\section{Autohydrolysis}

As mentioned before, autohydrolysis can be used to obtain carbohydrate-rich fractions. Carvalheiro et al. (2005) used isothermal autohydrolysis treatments to the production of xylooligosaccharides and solubilization of hemicellulose. Different temperatures (150 to $190^{\circ} \mathrm{C}$ ) and liquid-to-solid ratios $(8$ and $10 \mathrm{~g} / \mathrm{g})$ were used to determine the time course of the concentrations of residual hemicelluloses and reaction products.

\section{Ultrasound assisted extraction}

This kind of extraction uses ultrasounds of high intensity. These ultrasounds cause pressure variations that form microscopic bubbles that collapse almost after their formation. After the collapse of the bubbles, the generated shear forces will act on anything that is nearby resulting in a temperature increase. The ultrasound waves and the resulting cavitation occurrence break the cell walls, and, in result, the content of the cell wall will be released to the extraction medium. Ultrasound extractions take less time, use less solvent and lower extraction temperatures when compared with alternative extraction methods. All mentioned advantages result in higher extraction yields and higher purity polysaccharides. However, the intensity of the ultrasound can break down polymers which can affect the integrity of the polysaccharides, This method can be used to remove the starch from the final AX-rich extracts and thus enhance the prebiotic application of these extracts (Feng et al. 2015; Reis et al. 2015).

Ultrasound assisted extraction (UAE) can be used to extract xylans. Reis et al. (2015) used ultrasound assisted extraction to extract AX from BSG. In this study, the extraction time and energy consumption were compared to conventional alkaline extraction. With UAE the extraction time of AX was reduced from $7 \mathrm{~h}$ to $25 \mathrm{~min}$., recovering $60 \%$ of AX (similar amounts when compared to conventional alkaline extraction) from BSG. 
Table 3. Summary of different carbohydrates extraction methodologies and possible applications of BSG.

\begin{tabular}{|c|c|c|c|c|}
\hline Extraction method & Extraction conditions & Target compounds & Foreseen applications & Reference \\
\hline Hidrothermal autohydrolysis & $\begin{array}{l}\text { Temperature: } 150-190^{\circ} \mathrm{C} \\
\text { using liquid-to-solid ratios } \\
\text { of } 8 \text { and } 10 \mathrm{~g} / \mathrm{g}\end{array}$ & Oligosaccharides & & Carvalheiro et al. 2005 \\
\hline Ultrasound-assisted extraction & $\begin{array}{l}\text { Significant reduction of time } \\
(7 \mathrm{~h} \text { to } 25 \mathrm{~min}) \text { and energy } \\
\text { when compared to AKE, to } \\
\text { recover similar amounts } \\
\text { of } \mathrm{AX}\end{array}$ & AX-rich extracts & $\begin{array}{l}\text { Can be used in the removal } \\
\text { of starch from the final } \\
\text { AX-rich extracts which can } \\
\text { enhance the prebiotic } \\
\text { applications of these. }\end{array}$ & Reis et al. 2015 \\
\hline Dilute acid hydrolysis & $\begin{array}{l}\text { Liquid/solid ratio: } 8-12 \mathrm{~g} \mathrm{~g}^{-1} \text {; } \\
\mathrm{H}_{2} \mathrm{SO}_{4} \text { concentration: } \\
100-140 \mathrm{mg} \mathrm{g}^{-1} \text { dry } \\
\text { matter; reaction time: } \\
17-37 \text { min. Best condition: } \\
\text { liquid/solid ratio of } 8 \mathrm{~g} \\
\mathrm{~g}^{-1}, 100 \mathrm{mg} \text { of } \mathrm{H}_{2} \mathrm{SO}_{4} \mathrm{~g}^{-1} \\
\text { dry matter and } 17 \text { min. of } \\
\text { reaction time. Extraction } \\
\text { efficiency: } 92.7 \% \text {. }\end{array}$ & Hemicellulosic sugars & $\begin{array}{l}\text { The solid residue obtained, } \\
\text { can be useful for } \\
\text { applications as: to produce } \\
\text { cellulosic paste or to } \\
\text { generate glucose solutions } \\
\text { by enzymatic hydrolysis. }\end{array}$ & Mussatto and Roberto 2005 \\
\hline Dilute acid hydrolysis & $\begin{array}{l}\text { Liquid-to-solid ratio and acid } \\
\text { concentration conditions } \\
\text { were changed. Best } \\
\text { conditions of hemicellulose } \\
\text { hydrolysis: liquid-to-solid } \\
\text { ratio of } 10 \mathrm{~g} \mathrm{~g}^{-1} \text { and } \\
120 \mathrm{mg} \mathrm{H}_{2} \mathrm{SO}_{4} \mathrm{~g}^{-1} \\
\text { dry matter. }\end{array}$ & $\begin{array}{l}\text { Hemicellulose sugars (xylose } \\
\text { and arabinose) }\end{array}$ & $\begin{array}{l}\text { Dietary fiber-rich and protein- } \\
\text { rich flours, of potential use } \\
\text { as ingredients in baking } \\
\text { and formulated foods. } \\
\text { Production of value-added } \\
\text { products (xylitol, organic } \\
\text { acids, amino acids, } \\
\text { vitamins, ethanol } \\
\text { or butanediol). }\end{array}$ & Mussatto and Roberto 2006 \\
\hline Enzymatic hydrolysis & $\begin{array}{l}\text { Untreated sample, cellulose } \\
\text { and lignin sample and } \\
\text { cellulose pulp sample. } \\
\text { Cellulose and lignin - } \\
\text { cellulose conversion ratio } \\
3.5 \text { times higher than the } \\
\text { conversion ratio from the } \\
\text { untreated sample. } \\
\text { Cellulose pulp - cellulose } \\
\text { conversion } 4 \text { times higher } \\
\text { (91.8\% - glucose yield } \\
\text { of } 85.6 \% \text {. }\end{array}$ & Hemicellulose and lignin & & Mussatto et al. 2008 \\
\hline $\begin{array}{l}\text { Microwave assisted extraction, } \\
\text { dilute acid }\end{array}$ & $\begin{array}{l}140{ }^{\circ} \mathrm{C} \text {, to remove the residual } \\
\text { starch mixed with } \\
\beta \text {-glucans; suspension of } \\
\text { the residue left in water } \\
\text { and treated at } 180^{\circ} \mathrm{C} ; \\
\text { suspension of the residue } \\
\text { in } 0.1 \mathrm{M} \mathrm{KOH} \text { and treated } \\
\text { at } 180 \text { ॰ } \mathrm{C} \text {. Extraction of } \\
62 \% \text { of } \mathrm{BSG} \mathrm{AX}+\mathrm{AXOS} \text {, } \\
\text { presenting degrees of } \\
\text { polymerization ranging } \\
\text { between } 7 \text { and } 24 \text { xylose } \\
\text { residues, and a degree of } \\
\text { phenolic acids } \\
\text { esterification between } 5 \\
\text { and } 21 \%\end{array}$ & $A X$ and $A X O S$ & $\begin{array}{l}\text { BSG under study as potential } \\
\text { source of nutraceuticals } \\
\text { with potential prebiotic } \\
\text { effects and with } \\
\text { antioxidant activity. }\end{array}$ & Coelho et al. 2014 \\
\hline Microwave assisted extraction & $\begin{array}{l}2 \text { min at } 140-210^{\circ} \mathrm{C} \text {. Best } \\
\text { condition: } 210^{\circ} \mathrm{C} \text { during } \\
2 \text { min, allowing the } \\
\text { extraction of } 43 \% \text { of } \\
\text { total } \mathrm{AX} \text {. }\end{array}$ & $A X$ and $A X O S$ & $\begin{array}{l}\text { BSG under study as potential } \\
\text { source of nutraceuticals } \\
\text { with potential prebiotic } \\
\text { effects in the } \\
\text { fractions obtained. }\end{array}$ & $\begin{array}{l}\text { Rocha, Saraiva, and } \\
\text { Coimbra } 2011\end{array}$ \\
\hline
\end{tabular}

\section{Dilute acid hydrolysis}

In this hydrolysis, the heterocyclic ether bonds between sugar monomers in the polymeric chains formed by hemicelluloses and cellulose are broken by the protons released by the acid. When the above bonds break, there are compounds that are released (xylose, arabinose and glucose mainly). As the bonds in hemicellulose are weaker than the ones in cellulose, there is almost no damage in the cellulose and therefore a quantitative hydrolysis of the hemicelluloses can be made. With this process, the sugar yield is bigger and there is a low formation of degradation products. However, it is necessary to use the adequate reaction conditions to prevent sugar decomposition (Mussatto and Roberto 2005, 2006).

Mussatto and Roberto (2005) used this kind of hydrolysis to produce a liquor with high xylose content, used to produce xylitol. Different conditions of liquid/solid ratio $\left(8-12 \mathrm{~g} \mathrm{~g}^{-1}\right)$, sulfuric acid concentration $(100-140 \mathrm{mg}$ 
$\mathrm{g}^{-1}$ dry matter) and reaction time (17-37 min.) were used. The best condition for BSG acid hydrolysis was a liquid/ solid ratio of $8 \mathrm{~g} \mathrm{~g}^{-1}, 100 \mathrm{mg}$ of $\mathrm{H}_{2} \mathrm{SO}_{4} \mathrm{~g}^{-1}$ dry matter and $17 \mathrm{~min}$. of reaction time. The extraction efficiency of hemicellulose sugars was $92.7 \%$.

This hydrolysis method was also used by Mussatto and Roberto (2006) to recover hemicellulose sugars from BSG. The liquid-to-solid ratio and acid concentration conditions were changed to verify the influence on the hydrolysis of hemicellulose. The best conditions of hemicellulose hydrolysis were: liquid-to-solid ratio of $10 \mathrm{~g} \mathrm{~g}^{-1}$ and $120 \mathrm{mg} \mathrm{H}_{2} \mathrm{SO}_{4}$ $\mathrm{g}^{-1}$ dry matter. Under these conditions $76.2 \%$ of hemicellulose was hydrolyzed, and xylose and arabinose were recovered with 67 and $97.8 \%$ efficiency respectively.

This method can be useful as the products obtained can be applied in various applications, e.g. the production of cellulosic paste, the generation of glucose solutions by enzymatic hydrolysis, dietary fiber-rich and protein-rich flours, production of value-added products (xylitol, organic acids, amino acids, vitamins, ethanol or butanediol).

White, Yohannan, and Walker (2008) used acid hydrolysis combined with enzyme treatments to produce bioethanol. Pretreatment of dried BSG was made with $0,16 \mathrm{~N} \mathrm{HNO}_{3}$ at $121^{\circ} \mathrm{C}$ during $15 \mathrm{~min}$. followed by enzymatic digestion (for $18 \mathrm{~h}$ with cellulase and hemicellulase preparations). The final results showed a final composition $27 \mathrm{~g} \mathrm{~L}^{-1}$ of glucose, $16.7 \mathrm{~g} \mathrm{~L}^{-1}$ of xylose and $11.9 \mathrm{~g} \mathrm{~L}^{-1}$ of arabinose. Fermentation of this hydrolysate by Pichia stipitis and Kluyveromyces marxianus led to $8.3 \mathrm{~g} \mathrm{~L}^{-1}$ and $5.9 \mathrm{~g} \mathrm{~L}^{-1}$ of ethanol corresponding to conversion yields of 0.32 and 0.23

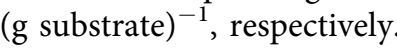

\section{Enzymatic hydrolysis}

Enzymatic hydrolysis can be used to produce fermentable sugars from cellulosic materials. The enzymes used are a mixture in which at least three major groups are involved in the hydrolysis of cellulose. There needs to be contact between the enzyme and the substrate (the hydrolysis is heterogeneous) so the enzymes have to pass through barriers (e.g. lignin), adsorb on the surface of the substrate and, in the end, catalyze the hydrolysis. The properties of the substrate, the contents of lignin and hemicelluloses affect the hydrolysis reaction. This method applied with other methods as dilute acid hydrolysis can be used in the production of bioethanol from BSG (Mussatto et al. 2008; White, Yohannan, and Walker 2008).

Mussatto et al. (2008) studied the effect of hemicelluloses and lignin on enzymatic hydrolysis of cellulose from BSG. In this study BSG was pretreated before the hydrolysis in order to obtain samples with different chemical composition. The pretreatments served to break the lignocellulosic structure. Diluted acid (removes hemicellulose part giving rise to a solid residue made of cellulose and lignin) and dilute alkali (removes the lignin) are pretreatments that can be used with this method. Mussatto et al. (2008) used three forms of BSG to study enzymatic hydrolysis: an untreated sample (original form), cellulose and lignin sample (pretreated with dilute acid) and cellulose pulp sample (sequential pretreated using dilute acid and dilute alkali solutions). Cellulose and lignin had a cellulose conversion ratio 3.5 times higher than the conversion ratio from the untreated sample. The cellulose pulp had a cellulose conversion 4 times higher: $91.8 \%$ (with a glucose yield of $85.6 \%$ ). This study concluded that for a higher efficiency of cellulose hydrolysis the content of hemicelluloses and lignin should be lowered.

\section{Microwave assisted extraction}

In microwave-assisted extraction the energy of the microwave is used to heat the solvent in contact with the sample. This causes the analytes to separate from the sample matrix and pass to the solvent. This kind of extraction uses more elevated temperatures which make this extraction faster than other kind of extractions, also consuming less energy. Additionally, wastes are not produced during this process. The quantity of solvents (solvents should have high selectivity towards the analyte of interest) used is also smaller when compared to the other techniques. This technique can be used to extract AX and AXOS from BSG. The compounds extracted can make BSG a source of nutraceuticals with potential prebiotic effect and antioxidant activity (AguilarReynosa et al. 2017; Coelho et al. 2014; Rocha, Saraiva, and Coimbra 2011).

Coelho et al. (2014) used microwave superheated water extraction to extract quantitatively AX and AXOS from BSG. In this study, the yield of AX and AXOS increased with the increase of temperature $\left(140^{\circ} \mathrm{C}\right.$ to $210^{\circ} \mathrm{C}$ for $2 \mathrm{~min}$.). However, the higher temperatures promoted depolymerization, debranching and deesterification of the polysaccharides and the formation of brown products due to Maillard reactions. The yield of AX and AXOS extracted at $180^{\circ} \mathrm{C}$ for $2 \mathrm{~min}$. was of $62 \%$.

Rocha, Saraiva, and Coimbra (2011) evaluated the adequacy of this technology for the quantitative extraction of AX or AXOS from BSG. It was used a range of temperatures from 140 to $210^{\circ} \mathrm{C}$ during $2 \mathrm{~min}$. In this study, the yield of AX extraction increased with the increase of the temperature. It was possible to extract $43 \%$ of total $\mathrm{AX}$ at $210^{\circ} \mathrm{C}$ during the $2 \mathrm{~min}$ of procedure.

\section{Others - proteins}

Proteins can also be extracted from BSG. In order to recover proteins, alkaline extraction followed by precipitation by acidification can be used, However, the temperature used may denature proteins and the salt could not be completely removed by dialysis. Ultrafiltration and ultrasound assisted extraction are two techniques that have been used to recover proteins from BSG (Tang et al. 2009; Tang et al. 2010).

\section{Ultrafiltration}

Ultrafiltration is a technique used to separate various compounds, however the concentration polarization and fouling may lower the permeate flux and interferer with the membrane selectivity. Both depend on the properties of the feed, 
Table 4. Summary of the advantages and disadvantages of the different BSG's extraction methodologies.

\begin{tabular}{|c|c|c|c|}
\hline Extraction method & Advantages & Disadvantages & Reference \\
\hline Supercritical carbon dioxide & Fast; selective; no residual solvents. & $\begin{array}{l}\text { High cost; low polarity; type of co- } \\
\text { solvent affects the efficiency of the } \\
\text { extraction of } \\
\text { antioxidant compounds. }\end{array}$ & $\begin{array}{l}\text { Junior, Leite, and Dragano 2014; } \\
\text { Spinelli et al. } 2016 .\end{array}$ \\
\hline Autohydrolysis & $\begin{array}{l}\text { Eco-friendly (does not use chemicals); } \\
\text { Less expensive. }\end{array}$ & $\begin{array}{l}\text { To be effective optimal conditions } \\
\text { have to be achieved. }\end{array}$ & $\begin{array}{l}\text { Carvalheiro et al. 2005; Meneses et al. } \\
\text { 2011; Ruiz et al. } 2013 \text {. }\end{array}$ \\
\hline Alkaline hydrolysis & $\begin{array}{l}\text { Low environmental impact; less sugar } \\
\text { degradation. }\end{array}$ & $\begin{array}{l}\text { Loss of fermentable sugars; } \\
\text { production of } \\
\text { inhibitory compounds. }\end{array}$ & $\begin{array}{l}\text { Alvira et al. 2010; Mussatto, Dragone, } \\
\text { and Roberto 2007; Wilkinson, } \\
\text { Smart, and Cook 2014; Xiao, Sun, } \\
\text { and Sun 2001. }\end{array}$ \\
\hline Solvent extraction & Less expensive. & $\begin{array}{l}\text { Time consuming; large amounts } \\
\text { of solvent. }\end{array}$ & $\begin{array}{l}\text { Luque de Castro and García-Ayuso } \\
\text { 1998; Meneses et al. } 2013 .\end{array}$ \\
\hline Ultrasound assisted extraction & $\begin{array}{l}\text { Faster; less solvent use; lower } \\
\text { temperature. }\end{array}$ & $\begin{array}{l}\text { Intensity of the ultrasound can break } \\
\text { down polymers which can affect } \\
\text { the polysaccharides. }\end{array}$ & Feng et al. 2015; Reis et al. 2015. \\
\hline Dilute acid hydrolysis & $\begin{array}{l}\text { Higher sugar yield; low formation } \\
\text { of inhibitors. }\end{array}$ & $\begin{array}{l}\text { Use of adequate reactions conditions } \\
\text { to prevent sugar decomposition; } \\
\text { low sugar concentration in } \\
\text { exit stream. }\end{array}$ & $\begin{array}{l}\text { Bhatt and Shilpa 2014; Mussatto and } \\
\text { Roberto 2005; Mussatto and } \\
\text { Roberto 2006. }\end{array}$ \\
\hline Enzymatic hydrolysis & $\begin{array}{l}\text { Run mostly in mild conditions, } \\
\text { normal temperatures and } \mathrm{pH} \\
\text { conditions; no inhibitors produced. }\end{array}$ & $\begin{array}{l}\text { Physical contact between the enzyme } \\
\text { and substrate is needed; Rate of } \\
\text { hydrolysis is often low }\end{array}$ & $\begin{array}{l}\text { Bhatt and Shilpa 2014; Mussatto } \\
\text { et al. 2008; White, Yohannan, and } \\
\text { Walker 2008. }\end{array}$ \\
\hline Microwave assisted extraction & $\begin{array}{l}\text { Faster; less energy used; smokes and } \\
\text { wastes are not produced; less } \\
\text { solvent used. }\end{array}$ & $\begin{array}{l}\text { High extraction pressure might } \\
\text { modify the chemical structures of } \\
\text { the compounds which might lead } \\
\text { to a reduction of the extraction } \\
\text { yield; low penetration of radiation } \\
\text { in bulk products; Non-uniform; } \\
\text { equipment more expensive. }\end{array}$ & $\begin{array}{l}\text { Aguilar-Reynosa et al. 2017; Coelho } \\
\text { et al. 2014; Rocha, Saraiva, and } \\
\text { Coimbra 2011; Zhang, Yang, and } \\
\text { Wang 2011. }\end{array}$ \\
\hline Ultrafiltration & Able to separate various compounds. & $\begin{array}{l}\text { Polarization and fouling may lower } \\
\text { the permeate flux and interfere } \\
\text { with the membrane selectivity. }\end{array}$ & Tang et al. 2009. \\
\hline
\end{tabular}

membrane molecular weight cut off (MWCO), transmembrane pressure and cross-flowrate.

Tang et al. (2009) applied ultrafiltration in the recovery of protein from BSG and compared it with rotary evaporator concentration. Two membranes of MWCO were used (5 and $30 \mathrm{kDA}$ ) and the protein content was of $20.09 \pm 1.40 \%$ for the $5 \mathrm{kDA}$ membrane and $15.98 \pm 0.58 \%$ for the $30 \mathrm{kDA}$.

\section{Ultrasound assisted extraction}

As mentioned before, UAE can be used to extract valueadded compounds like carbohydrates, but it can also be used to extract proteins from BSG.

Tang et al. (2010) used UAE to extract proteins from BSG. Three variables were used (extraction time, ultrasonic power and solid-liquid ratio). The best conditions to perform the extraction of proteins from BSG were $81.4 \mathrm{~min}$. of extraction time, $88.2 \mathrm{~W} / 100 \mathrm{ml}$ of extractant of ultrasonic power and solid-liquid ratio of $2.0 \mathrm{~g} / 100 \mathrm{ml}$ being the yield of protein obtained of $104.3 \mathrm{mg} / \mathrm{g}$ of BSG. In the control experiment (extraction time of $81.4 \mathrm{~min}$, ultrasonic power of $98.2 \mathrm{~W} / 100 \mathrm{ml}$ of extractant and solid-liquid ratio of, the yield of protein was of $96.4 \pm 3.5 \mathrm{mg} / \mathrm{g}$.

\section{Electric-field based technologies}

Electric-field technologies are emergent and novel technologies in which electric current is applied to the biomaterials. The use of these technologies has advantages (higher extraction and diffusion of compounds, stabilization of the biomaterials and others). Electric-field based technologies can be differentiated depending on the electric flow, the application of pulses, the strength of the electric field, heat extension and others. Electric-field technologies can be separated in: pulsed (pulsed electric fields - non-thermal inactivation of microbial cells, extraction of thermal labile compounds, among others; pulsed ohmic heating - thermal extraction of compounds; high voltage electric discharges - extraction of biocompounds) and non-pulsed (ohmic heating - high temperature short time pasteurization and sterilization, thermal extraction, among others; moderate electric fields - non thermal inactivation of microbial cells, extraction of biocompounds; electrofiltration - separation of biocompounds; electrophoresis - protein separation). These techniques bring advantages to the re-use of by-products (Rocha et al. 2018) (Table 4).

\section{Conclusions}

From an economical and environmental point of view there has been an effort to find a re-use to agro-industrial byproducts. BSG is the most abundant by-product of the brewing industry and still has a low cost with very limited applications, being mainly applied in animal feed despites its high value mainly as source of bioactive molecules. In order to use this by-product as a value-added resource considering the number of bioactive compounds available with a wide range of applications, it is necessary to further develop the existing techniques of extraction and find new techniques and new possible applications to the BSG.

Techniques described above as supercritical carbon dioxide extraction, autohydrolysis, ultrasound assisted extraction, 
dilute acid hydrolysis, alkaline hydrolysis, solvent extraction, enzymatic extraction, microwave assisted extraction and ultrasonic assisted extraction, can be used to extract the bioactive compounds present in BSG. The choice of extraction method will depend on target compound as well as the extraction conditions combined with the economic and environmental impact. Techniques as electric-field based should also be taken in consideration has they bring advantages to the re-use of the by-products. However, the re-use of the BSG as a value-added by-product is inevitable in the circular economy perspective and in future integrated approaches to get zero waste must be considered.

\section{Acknowledgments}

The authors would like to thank to the projects Co-promoção, NORTE-01-0145-FEDER-000004 and OCI-01-0145-FEDER-006684. Furthermore, the authors would also acknowledge the FCT projects UID/Multi/50016/2019, UID/BIO/04469/2013. The author T. BonifácioLopes would also like to acknowledge the grant UMINHO/BD/11/2016

\section{ORCID}

T. Bonifácio-Lopes (ID) http://orcid.org/0000-0002-5658-5779 José A. Teixeira iD http://orcid.org/0000-0002-4918-3704 Manuela Pintado (D) http://orcid.org/0000-0002-0760-3184

\section{References}

Aguedo, M., H. A. Ruiz, and A. Richel. 2015. Non-alkaline solubilization of arabinoxylans from destarched wheat bran using hydrothermal microwave processing and comparison with the hydrolysis by an endoxylanase. Chemical Engineering and Processing: Process Intensification 96:72-82. https://doi.org/10.1016/j.cep.2015.07.020.

Aguilar-Reynosa, A., A. Romaní, R. Ma. Rodríguez-Jasso, C. N. Aguilar, G. Garrote, and H. A. Ruiz. 2017. Microwave heating processing as alternative of pretreatment in second-generation biorefinery: An overview. Energy Conversion and Management 136:50-65. doi: 10.1016/j.enconman.2017.01.004.

Alvira, P., E. Tomás-Pejó, M. Ballesteros, and M. J. Negro. 2010. Pretreatment technologies for an efficient bioethanol production process based on enzymatic hydrolysis: A review. Bioresource Technology 101 (13):4851-61. doi: 10.1016/j.biortech.2009.11.093.

Bartolomé, B., C. B. Faulds, and G. Williamson. 1997. Enzymic release of ferulic acid from barley spent grain. Journal of Cereal Science 25 (3):285-8. doi: 10.1006/jcrs.1996.0091.

Bhatt, S. M., and Shilpa. 2014. Lignocellulosic feedstock conversion, inhibitor detoxification and cellulosic hydrolysis - A review. Biofuels 5 (6):633-49. doi: 10.1080/17597269.2014.1003702.

Caleffi, E. R., G. Krausová, I. Hyršlová, L. L. R. Paredes, M. M. Dos Santos, G. L. Sassaki, R. A. C. Gonçalves, and A. J. B. de Oliveira. 2015. Isolation and prebiotic activity of inulin-type fructan extracted from Pfaffia glomerata (Spreng) Pedersen roots. International Journal of Biological Macromolecules 80:392-9. doi: 10.1016/j.ijbiomac.2015.06.053.

Carvalheiro, F., M. P. Esteves, J. C. Parajó, H. Pereira, and F. M. Gírio. 2004. Production of oligosaccharides by autohydrolysis of brewery's spent grain. Bioresource Technology 91 (1):93-100. doi: 10.1016/ S0960-8524(03)00148-2.

Carvalheiro, F., G. Garrote, J. C. Parajó, H. Pereira, and F. M. Gírio. 2005. Kinetic modeling of brewer's spent grain autohydrolysis. Biotechnology Progress 21 (1):233-43. doi: 10.1021/bp049764z.

Coelho, E., M. A. M. Rocha, J. A. Saraiva, and M. A. Coimbra. 2014. Microwave superheated water and dilute alkali extraction of brewers' spent grain arabinoxylans and arabinoxylo-oligosaccharides.
Carbohydrate Polymers 99:415-22. doi: 10.1016/j.carbpol.2013.09. 003.

Courtin, C. M., K. Swennen, P. Verjans, and J. A. Delcour. 2009. Heat and $\mathrm{pH}$ stability of prebiotic arabinoxylooligosaccharides, xylooligosaccharides and fructooligosaccharides. Food Chemistry 112 (4): 831-7. doi: 10.1016/j.foodchem.2008.06.039.

del Campo, I., I. Alegría, M. Zazpe, M. Echeverría, and I. Echeverría 2006. Diluted acid hydrolysis pretreatment of Agri-food wastes for bioethanol production. Industrial Crops and Products 24 (3):214-21. doi: 10.1016/j.indcrop.2006.06.014.

del Río, J. C., P. Prinsen, and A. Gutiérrez. 2013. Chemical composition of lipids in brewer's spent grain: A promising source of valuable phytochemicals. Journal of Cereal Science 58 (2):248-54. doi: 10.1016/j.jcs.2013.07.001

Comissão Europeia. 2012. Regulamento (UE) N. ${ }^{\circ} \quad 432 / 2012 \mathrm{da}$ Comissão. Jornal Oficial Da União Europeia 432.

Fărcaş, A. C., S. A. Socaci, F. V. Dulf, M. Tofană, E. Mudura, and Z. Diaconeasa. 2015. Volatile profile, fatty acids composition and total phenolics content of brewers' spent grain by-product with potential use in the development of new functional foods. Journal of Cereal Science 64:34-42. doi: 10.1016/j.jcs.2015.04.003.

Feng, S., Z. Luo, B. Tao, and C. Chen. 2015. Ultrasonic-assisted extraction and purification of phenolic compounds from sugarcane (Saccharum officinarum L.) rinds. LWT - Food Science and Technology 60 (2):970-6. doi: 10.1016/j.lwt.2014.09.066.

Gangopadhyay, N., D. K. Rai, N. P. Brunton, E. Gallagher, and M. B. Hossain. 2016. Antioxidant-guided isolation and mass spectrometric identification of the major polyphenols in barley (Hordeum vulgare) grains. Food Chemistry 210:212. doi: 10.1016/j.foodchem.2016.04. 098.

Gibson, G. R., R. Hutkins, M. E. Sanders, S. L. Prescott, R. A. Reimer, S. J. Salminen, K. Scott, C. Stanton, K. S. Swanson, P. D. Cani, et al. 2017. Expert consensus document: The International Scientific Association for Probiotics and Prebiotics (ISAPP) consensus statement on the definition and scope of prebiotics. Nature Reviews Gastroenterology \& Hepatology 14 (8):491-502. doi: 10.1038/nrgastro.2017.75.

Gómez, B., B. Míguez, A. Veiga, J. C. Parajó, and J. L. Alonso. 2015. Production, purification, and in vitro evaluation of the prebiotic potential of arabinoxylooligosaccharides from brewer's spent grain. Journal of Agricultural and Food Chemistry 63 (38):8429-38. doi: 10. 1021/acs.jafc.5b03132.

Gonçalves, G. da C., P. K. Nakamura, D. F. Furtado, and M. T. Veit 2017. Utilization of brewery residues to produces granular activated carbon and bio-oil. Journal of Cleaner Production 168:908-16. doi: 10.1016/j.jclepro.2017.09.089.

Hosseini Koupaie, E., S. Dahadha, A. A. Bazyar Lakeh, A. Azizi, and E. Elbeshbishy. 2018. Enzymatic pretreatment of lignocellulosic biomass for enhanced biomethane production - A review. Journal of Environmental Management 233:774-58. doi: 10.1016/j.jenvman. 2018.09.106.

Kirin Holdings. 2018. Global beer production by country in 2017.

Junior, M. R. M., A. V. Leite, and N. R. V. Dragano. 2014. Supercritical fluid extraction and stabilization of phenolic compounds from natural sources - Review (supercritical extraction and stabilization of phenolic compounds). The Open Chemical Engineering Journal 5 (1):51-60. doi: 10.2174/1874123101004010051.

Kabel, M. A., H. A. Schols, and A. G. J. Voragen. 2002. Complex xylooligosaccharides identified from hydrothermally treated Eucalyptus wood and brewery's spent grain. Carbohydrate Polymers 50 (2): 191-200. doi: 10.1016/S0144-8617(02)00022-X.

Li, Z., J. Jiang, Y. Fu, Z. Wang, and M. Qin. 2017. Recycling of prehydrolysis liquor to improve the concentrations of hemicellulosic saccharides during water pre-hydrolysis of aspen woodchips. Carbohydrate Polymers 174:385-91. doi: 10.1016/j.carbpol.2017.06. 046.

Luque de Castro, M. D., and L. E. García-Ayuso. 1998. Soxhlet extraction of solid materials: An outdated technique with a promising innovative future. Analytica Chimica Acta 369 (1-2):1-10. doi: 10. 1097/00005053-190406000-00004. 
Lynch, K. M., E. J. Steffen, and E. K. Arendt. 2016. Brewers' spent grain: A review with an emphasis on food and health. Journal of the Institute of Brewing 122 (4):553-68. doi: 10.1002/jib.363.

Mancini, G., S. Papirio, G. Riccardelli, P. N. L. Lens, and G. Esposito. 2018. Trace elements dosing and alkaline pretreatment in the anaerobic digestion of rice straw. Bioresource Technology 247:897-903. doi: 10.1016/j.biortech.2017.10.001.

McCarthy, A. L., Y. C. O'Callaghan, A. Connolly, C. O. Piggott, R. J. Fitzgerald, and N. M. O'Brien. 2012. Phenolic extracts of brewers' spent grain (BSG) as functional ingredients - Assessment of their DNA protective effect against oxidant-induced DNA single strand breaks in U937 cells. Food Chemistry 134 (2):641-6. doi: 10.1016/j. foodchem.2012.02.133.

McCarthy, A. L., Y. C. O'Callaghan, A. Connolly, C. O. Piggott, R. J. FitzGerald, and N. M. O’Brien. 2013a. In vitro antioxidant and antiinflammatory effects of brewers' spent grain protein rich isolate and its associated hydrolysates. Food Research International 50 (1): 205-12. doi: 10.1016/j.foodres.2012.10.022.

McCarthy, A. L., Y. C. O'Callaghan, S. Neugart, C. O. Piggott, A. Connolly, M. A. K. Jansen, A. Krumbein, M. Schreiner, R. J. FitzGerald, and N. M. O'Brien. 2013b. The hydroxycinnamic acid content of barley and brewers' spent grain (BSG) and the potential to incorporate phenolic extracts of BSG as antioxidants into fruit beverages. Food Chemistry 141 (3):2567-74. doi: 10.1016/j.foodchem. 2013.05.048.

Meneses, N. G. T., S. Martins, J. A. Teixeira, and S. I. Mussatto. 2013. Influence of extraction solvents on the recovery of antioxidant phenolic compounds from brewer's spent grains. Separation and Purification Technology 108:152-8. doi: 10.1016/j.seppur.2013.02.015.

Meneses, N. G. T., A. R. M. Sampaio, J. A. Teixeira, and S. I. Mussatto. 2011. Extraction of aroma compounds by autohydrolysis of brewers' spent grains. Book of Abstracts of the 11th International Chemical and Biological Engineering Conference, Lisboa, 370-1.

Mikulski, D., and G. Kłosowski. 2018. Efficiency of dilute sulfuric acid pretreatment of distillery stillage in the production of cellulosic ethanol. Bioresource Technology 268:424-33. doi: 10.1016/j.biortech.2018. 08.005.

Mitsou, E. K., N. Panopoulou, K. Turunen, V. Spiliotis, and A. Kyriacou. 2010. Prebiotic potential of barley derived $\beta$-glucan at low intake levels: A randomised, double-blinded, placebo-controlled clinical study. Food Research International 43 (4):1086-92. doi: 10.1016/ j.foodres.2010.01.020.

Muniandy, P., A. B. Shori, and A. S. Baba. 2015. Comparison of the effect of green, white and black tea on Streptococcus thermophilus and Lactobacillus spp. in yogurt during refrigerated storage. Journal of the Association of Arab Universities for Basic and Applied Sciences 8:1-8. doi: 10.1016/j.jaubas.2015.11.002.

Mussatto, S. I. 2014. Brewer's spent grain: A valuable feedstock for industrial applications. Journal of the Science of Food and Agriculture 94 (7):1264-75. doi: 10.1002/jsfa.6486.

Mussatto, S. I., G. Dragone, and I. C. Roberto. 2006. Brewers' spent grain: Generation, characteristics and potential applications. Journal of Cereal Science 43 (1):1-14. doi: 10.1016/j.jcs.2005.06.001.

Mussatto, S. I., G. Dragone, and I. C. Roberto. 2007. Ferulic and p-coumaric acids extraction by alkaline hydrolysis of brewer's spent grain. Industrial Crops and Products 25 (2):231-7. doi: 10.1016/j.indcrop. 2006.11.001.

Mussatto, S. I., M. Fernandes, A. M. F. Milagres, and I. C. Roberto. 2008. Effect of hemicellulose and lignin on enzymatic hydrolysis of cellulose from brewer's spent grain. Enzyme and Microbial Technology 43 (2):124-9. doi: 10.1016/j.enzmictec.2007.11.006.

Mussatto, S. I., M. Fernandes, G. J. M. Rocha, J. J. M. Órfão, J. A. Teixeira, and I. C. Roberto. 2010. Production, characterization and application of activated carbon from brewer's spent grain lignin. Bioresource Technology 101 (7):2450-7. doi: 10.1016/j.biortech.2009. 11.025 .

Mussatto, S. I., and I. C. Roberto. 2005. Acid hydrolysis and fermentation of brewer's spent grain to produce xylitol. Journal of the Science of Food and Agriculture 85 (14):2453-60. doi: 10.1002/jsfa.2276.
Mussatto, S. I., and I. C. Roberto. 2006. Chemical characterization and liberation of pentose sugars from brewer's spent grain. Journal of Chemical Technology \& Biotechnology 81 (3):268-74. doi: 10.1002/ jctb.1374.

Pires, E. J., H. A. Ruiz, J. A. Teixeira, and A. A. Vicente. 2012. A new approach on brewer's spent grains treatment and potential use as lignocellulosic yeast cells carriers. Journal of Agricultural and Food Chemistry 60 (23):5994-9. doi: 10.1021/jf300299m.

Rajan, K., and D. J. Carrier. 2014. Effect of dilute acid pretreatment conditions and washing on the production of inhibitors and on recovery of sugars during wheat straw enzymatic hydrolysis. Biomass and Bioenergy 62:222-7. doi: 10.1016/j.biombioe.2014.01. 013.

Reis, S. F., E. Coelho, M. A. Coimbra, and N. Abu-Ghannam. 2015. Improved efficiency of brewer's spent grain arabinoxylans by ultrasound-assisted extraction. Ultrasonics Sonochemistry 24:155-64. doi: 10.1016/j.ultsonch.2014.10.010.

Rocha, C. M. R., Z. Genisheva, P. Ferreira-Santos, R. Rodrigues, A. A. Vicente, J. A. Teixeira, and R. N. Pereira. 2018. Electric field-based technologies for valorization of bioresources. Bioresource Technology 254:325-39. doi: 10.1016/j.biortech.2018.01.068.

Rocha, M. A. M., J. A. Saraiva, and M. A. Coimbra. 2011. Microwaveassisted Extraction of brewer's Spent Grain Arabinoxylans. 7th International Conference on Polysaccharides-Glycoscience, 1-5.

Ruiz, H. A., R. M. Rodríguez-Jasso, B. D. Fernandes, A. A. Vicente, and J. A. Teixeira. 2013. Hydrothermal processing, as an alternative for upgrading agriculture residues and marine biomass according to the biorefinery concept: A review. Renewable and Sustainable Energy Reviews 21:35-51. doi: 10.1016/j.rser.2012.11.069.

Shahabazuddin, M., T. Sarat Chandra, S. Meena, R. K. Sukumaran, N. P. Shetty, and S. N. Mudliar. 2018. Thermal assisted alkaline pretreatment of rice husk for enhanced biomass deconstruction and enzymatic saccharification: Physico-chemical and structural characterization. Bioresource Technology 263:199-206. doi: 10.1016/j.biortech.2018.04.027.

Silva, J. P., S. Sousa, J. Rodrigues, H. Antunes, J. J. Porter, I. Gonçalves, and S. Ferreira-Dias. 2004. Adsorption of acid orange 7 dye in aqueous solutions by spent brewery grains. Separation and Purification Technology 40 (3):309-15. doi: 10.1016/j.seppur.2004.03. 010.

Silva, S., E. M. Costa, C. Calhau, R. M. Morais, and M. E. Pintado. 2017. Anthocyanin extraction from plant tissues: A review. Critical Reviews in Food Science and Nutrition 57 (14):3072-83. doi: 10. 1080/10408398.2015.1087963.

Spinelli, S., A. Conte, L. Lecce, L. Padalino, and M. A. Del Nobile. 2016. Supercritical carbon dioxide extraction of brewer's spent grain. The Journal of Supercritical Fluids 107:69-74. doi: 10.1016/j.supflu. 2015.08.017.

Steiner, J., S. Procopio, and T. Becker. 2015. Brewer's spent grain: Source of value-added polysaccharides for the food industry in reference to the health claims. European Food Research and Technology 241 (3):303-15. doi: 10.1007/s00217-015-2461-7.

Tang, D. S., Y. J. Tian, Y. Z. He, L. Li, S. Q. Hu, and B. Li. 2010. Optimisation of ultrasonic-assisted protein extraction from brewer's spent grain. Czech Journal of Food Sciences 28 (1):9-17. doi: 10. 17221/178/2009-CJFS.

Tang, D. S., G. M. Yin, Y. Z. He, S. Q. Hu, B. Li, L. Li, H.-L. Liang, and D. Borthakur. 2009. Recovery of protein from brewer's spent grain by ultrafiltration. Biochemical Engineering Journal 48 (1):1-5. doi: 10.1016/j.bej.2009.05.019.

Vieira, E., M. A. M. Rocha, E. Coelho, O. Pinho, J. A. Saraiva, I. M. P. L. V. O. Ferreira, and M. A. Coimbra. 2014. Valuation of brewer's spent grain using a fully recyclable integrated process for extraction of proteins and arabinoxylans. Industrial Crops and Products 52: 136-43. doi: 10.1016/j.indcrop.2013.10.012.

Wang, X., M. Huang, F. Yang, H. Sun, X. Zhou, Y. Guo, X. Wang, and M. Zhang. 2015. Rapeseed polysaccharides as prebiotics on growth and acidifying activity of probiotics in vitro. Carbohydrate Polymers 125:232-40. doi: 10.1016/j.carbpol.2015.02.040. 
White, J. S., B. K. Yohannan, and G. M. Walker. 2008. Bioconversion of brewer's spent grains to bioethanol. FEMS Yeast Research 8 (7): 1175-84. doi: 10.1111/j.1567-1364.2008.00390.x.

Wilkinson, S., K. A. Smart, and D. J. Cook. 2014. Optimisation of alkaline reagent based chemical pre-treatment of brewers spent grains for bioethanol production. Industrial Crops and Products 62:219-27. doi: 10.1016/j.indcrop.2014.08.036.

Xiao, B., X. F. Sun, and R. C. Sun. 2001. Chemical, structural, and thermal characterizations of alkali-soluble lignins and hemicelluloses, and cellulose from maize stems, rye straw, and rice straw. Polymer
Degradation and Stability 74 (2):307-19. doi: 10.1016/S01413910(01)00163-X.

Zhang, H. F., X. H. Yang, and Y. Wang. 2011. Microwave assisted extraction of secondary metabolites from plants: Current status and future directions. Trends in Food Science \& Technology 22 (12): 672-88. doi: 10.1016/j.tifs.2011.07.003.

Zhang, Y., X. Kang, Z. Wang, X. Kong, L. Li, Y. Sun, S. Zhu, S. Feng, X. Luo, and P. Lv. 2018. Enhancement of the energy yield from microalgae via enzymatic pretreatment and anaerobic co-digestion. Energy 164:400-7. doi: 10.1016/j.energy.2018.08.124. 